\title{
The institutionalization of Off-Road Wheelchair Riding in France (1990-2015): 'Truly a sport of sharing and diversity'.
}

\section{Gaël Villoing}

gael.villoing@univ-ag.fr

Actes EA 3596, Université Antilles Guyane, Pointe à Pitre, France

\section{Perera Eric}

Santesih EA4614, Université de Montpellier, Montpellier, France

\section{Nathalie Le Roux}

Santesih EA4614, Université de Montpellier, Montpellier, France

\section{Résumé}

Le mouvement handisport connaît, en France, depuis les années 1980, une diversification de ses pratiques, notamment avec l'arrivée progressive des activités physiques de pleine nature (Marcellini et Villoing, 2014). L'accès aux espaces naturels (montagneux, maritimes, aériens) est aujourd'hui devenu possible grâce aux progrès technologiques, et à une aspiration de plus en plus grande des personnes handicapées à accéder à des espaces réputés inaccessibles. La pratique du fauteuil tout terrain (FTT), apparue en France en 1991, est un exemple de pratiques nées de l'initiatives de passionnés qui, après un accident, bricolent 'au fond de leur garage' du matériel sportif afin de retrouver une pratique d'avant. Les pionniers du FTT, à qui nous avons donné la parole ( 2 entretiens d'histoire de vie) dans ce travail, ont trouvé dans cette pratique un moyen de retrouver des sensations passées en milieu montagnard mais également une activité touristique via des expéditions dans des pays étrangers. Cette activité va se développer grâce à la collaboration entre ces 'passionnés', ces 'bricoleurs', des acteurs fédéraux et politiques locaux, puis des industriels. Ce travail a pour objet de présenter les conditions d'institutionnalisation et de 'sportivisation' (Guay, 1993) du FTT en France qui semble être devenu aujourd'hui un véritable outil de participation sociale.

Mots clés : fauteuil tout terrain, handisport, pionniers, bricoleurs, institutionnalisation, sportivisation.

\begin{abstract}
The parasports movement is marked, in France and since the $1980 \mathrm{~s}$, by a diversification of practices, notably with the gradual development of physical nature activities (Marcellini and Villoing, 2014). The access to natural spaces (mountainous, maritime, aerial) has become possible through technological progress and an always growing yearning for disabled people to access these spaces which are reputed as being inaccessible. Off-Road Wheelchair (ORWC), which started in France in 1991, is an example of the practices which are born from the initiative of enthusiasts who, after an accident, 'mess around in their workshop' with sporting equipment in order to rediscover their former practice. The pioneers of ORWC, to whom we gave voice ( 2 life history interviews) in this work, found in this practice a way to reclaim their former sensations in a mountainous milieu, but also a more touristic activity through expeditions to foreign countries. This activity was able to develop thanks to a collaboration between these 'enthusiasts', the 'handymen', local federal and political protagonists, and finally some industrialists. The aim of this work is to present conditions of institutionalization and 'sportivization' of ORWC (Guay, 1993) in France, seemingly turning it nowadays into a true tool of social participation.
\end{abstract}

Keywords : Off-road Wheelchair, Parasports, pioneers, handymen, electric off-road wheelchair. 


\section{Introduction}

Since the 1980s, the French sporting movement for physically disabled people has gone through deep transformations from an organizational and cultural point of view. Initiated in 1954 through the creation of a disabled war veterans association (Association Sportive de Mutilés de France, ASMF [Disabled War Veterans Sporting Association of France]), the movement initially promoted sport as a means for functional reeducation and social readaptation (Ruffié and Ferez 2013). During the 20th century, it progressively drifted towards a more competitive model, enabling it to come closer to the ordinary sporting system, and more specifically to the International Olympics Movement (id.: 113-114). However, since the 1980s, as well as managing high-level sports, the Handisport French Federation (FFH) ${ }^{1}$, established in 1977, strives to integrate new sporting activities, evidencing the new ambitions of people designated as disabled in the field of leisure activities. The development of physical nature activities for people with motor or sensory deficiencies illustrates this new situation. In 2008 , 'over $40 \%$ of the members, approximately 500 clubs and 200 annual events, are oriented towards nature activities' (HM, $\left.\mathrm{n}^{\circ} 132,2008: 43\right)$. This enthusiasm lead Gérard Masson, President of the FFH, to declare that 'nature sports must be given their proper place within the new federal sporting project' $\left(H M, \mathrm{n}^{\circ} 137,2009: 20\right)$. These practices were among the first to be invested by those who instigated the French movement of sports for the "mobility impaired" (Ferez et al. 2013). The key protagonists of the founding association, Philippe Berthe and Pierre Volait ${ }^{2}$, were 'standing' skiers ${ }^{3}$, and turned ski into one of the leading sports of the movement, alongside wheelchair basket-ball, swimming, athletics or table-tennis. After being trained by Austrian amputee skiers, Berthe organized, as early as 1955, stand-up sky training courses, followed by international events hosted in Chamonix from 1959 onwards. He also campaigned for the creation of training courses for the volunteer overseers (Ruffié and Perera 2013). Nowadays, with the expansion of 'fun' sports (Loret 1995), new adapted sports are appearing (sitting ski, sailing, canoe-kayak, surfing). Whether they are developed within reeducation centers, such as kayak at the center in Kerpape in Brittany and sitting ski at the center of Saint-Hilaire du Touvet in Grenoble, or born from individual initiative in the way of surfing and off-road wheelchair (ORWC), these new sporting practices attract more and more members of the Handisport French Federation. According to Cédric Garreau, the current National Technical Director of the FFH and in charge of nature sports and activities, in addition to the 5000 people with annual memberships for nature sports and activities, which represents approximately one third of the total number 
of FFH members (17025 in 2012), 'the APPN [nature activities] represent $80 \%$ of the temporary licenses delivered throughout the year' (Marcellini and Villoing 2014, 135).

The emergence of nature activities acts as evidence of the main issues of that period. To begin with, after the 1980s, the competitive model of the FFH was questioned because of 'the dispersion of cultures and sporting customs' (Ruffié and Ferez 2013, 201) which punctuate that period of time. The arrival of a new audiences followed by the development of alternative and autonomous sporting events progressively called into question the Olympic model which had been followed, up until then, by the federal movement. Next, the progress in the field of national policies, promoting the social participation of disabled people, induced an intervention process favoring access to ordinary activities. Thence, 'innovation and creativity are exhibited (more strongly) by the elected representatives, the managers, the current and potential members of the FFH when the aim is to answer the ambition (of the disabled people) for practicing nature physical activities' (Marcellini and Villoing 2014, 23).

The institutionalization of ORWC in France, between the 1990s and 2015, which we propose to study in this article, is seated within the historical reasoning of this evolution of the parasports movement. Similarly to what was observed in the case of "sitting" ski, (Le Roux, Haye and Perera 2014), ORWC was at first restricted to a handful of injured people who had become quadri- or paraplegic and who sought to regain a space for their previous practices which now seemed, a priori, difficult of access. ORWC is currently recognized and overseen by the FFH. In this context, how did all-terrain wheelchair riding, impelled by its enthusiasts, become institutionalized and turned into a tool of social participation by making mountains accessible?

In this context, we will seek to evidence the emergence of ORWC in France through interviews which were carried out with the pioneers of this activity, Jean François Porret (JFP) and Gilles Bouchet (GB), the first people to ride off-road wheelchairs in France. These pioneers were asked to retrace their personal history and, more precisely, the period relating to their practice of ORWC. The aim here is to accomplish an exploratory work on the history of all-terrain wheelchair riding in France, based on discourses which 'come from the bottom' (Ferrarotti 1983). These interviews, of the 'life history' ${ }^{4}$ type, promote the surfacing of a 'micro-history' (Revel 1996) through the analysis of the experience of individuals, based on the traces, the discourses and even the clues which the protagonists left behind. We will complete these discourses with two journals, Handisport Magazine and Handisport Le Mag5 
(referenced as HM and Hlm in the following text), consulted from 1990 to 2015, to highlight the steps leading to the integration of ORWC into the parasports federal movement.

\section{The arrival of off-road wheelchairs in France (1990): 'reclaiming prior practices'.}

ORWC riding started out in France during the summer of $1990^{6}$, when Jean-François Porret, aged 45 at the time and quadriplegic, brought back a 'Cobra' wheelchair from the United States in order to practice hiking in the mountains. Originally, this wheelchair was created by John Castellano, an MIT (Massachusetts Institute of Technology) graduate and NASA engineer, near the end of the 1980s. The latter was inspired by 'mountain bike' technology and by the chairs used for athletics to develop a contraption which would allow to 'overcome the (functional) limitations of the traditional (wheel) chairs used in towns and cities' $\left(H M \mathrm{n}^{\circ} 99,1999: 40\right)$. At the time, Porret was a computer engineer for Hewlett Packard and worked in California in the United States. Fascinated by mountain sports, he suffered a paragliding accident in 1989. It was during his stay at the care center that he met Castellano, who had come to demonstrate his new wheelchair. That is when he discovered an 'extraordinary contraption' which would allow him to continue in 'his prior practices', mountain hiking, but also alpinism and 'Himalayism'. Upon his return to France, one year after his accident, and thanks to the Cobra $^{7}$ which his 'mates' gave him as a gift, he became the first $\mathrm{ORWC}^{8}$ rider in France.

During the 1990s, Porret went on many outings in France with his friends and family, hikers or mountain bikers, who could tow him up the hills in order for him to then take the descents in total autonomy. At the same time, he made sure to take notes on all the 'parameters of the outing, keepingd in mind the idea of being able to share it all'. The notes will later allow him to create a mapping of the trails which are accessible to ORWC, and which he released on his website from the year $2000^{9}$ onwards. Porret hopes to see ORWC riding develop in France, an activity which he is, for the moment, the only 'alien' to practice. The aim is thus to "generalize" hiking amongst people who are wheelchair-bound and enable a closer contact with nature.

Beyond the activity of mountain hiking, Porret would also like to come back to another form of practice which would be closer to trekking ${ }^{10}$. To him, these 'expeditions', which are much more difficult to implement, represent the ultimate step in the path to recovering his previous life. He had the project of going abroad, anywhere that had relief 
which seemed 'ORWC-izable', even to the most remote places like Tibet. The Himalaya was a voyage which he had already prepared for before his accident and for which he had already filed all the appropriate paperwork with the Chinese authorities. With his disability, the logistics were more complex, inducing him to progressively put to test his physical and mental capacity to resist outdoor living conditions, to be autonomous, but also to test his 'Cobra'. In 1991, a first expedition to the north of Spain, in the Sierra de Guara natural park, was undertaken. After this satisfactory first trial, a second expedition was organized in Morocco in April, 1992, in the south of the Toubkal mountain range, which was much more taxing both physically and for the equipment. Indeed, it involved amongst other things, staying with the locals and sleeping on floor mats, with the risk of bedsores that this implies, undertaking long crossings over broken ground, and being towed by animals (mules, camels). During these first expeditions, he travelled with his wife and friends, and surrounded himself with doctors and/or nurses. In 1993, only four years after his accident, Porret asked for, and was granted, permission from the Chinese authorities to launch an expedition in Tibet. The main obstacle at this point was the medical corps. The doctors' apprehensions, mainly linked to their lack of knowledge relating the capacities of quadriplegic people to resist the extreme conditions of high altitude, pushed him to seek out assistance from a research laboratory specializing in physiology applied to sports. He was used as "guinea pig" by taking part in a research protocol, implemented for the occasion, aiming to test the effects of altitude on the physiological capacities of quadriplegic people.

'[...] For this expedition to Tibet, there was one main parameter: can "quadris" live at high altitude? And so one of the reeducation doctors told me that I wouldn't survive, that it was impossible, so that was quite an issue. So for that aspect, I tried to broach it by finding someone who would agree, and I found the support of two profs, professor M. and professor G., who really helped me [the latter], he had a physiology applied to sports lab. And so, they ran a whole series of tests on me, breathing capacity, etcetera, and they had developed an altitude training protocol, then they sent to me here some high-altitude balloons for me to work with the secretary of my physiotherapist, because my physiotherapist was against it, thinking that I wouldn't survive. We went to the Aiguille du Midi [mountain in the Mont Blanc] next, and they did loads of tests there too, to see how it went, and finally they gave me the green light to go.' (JFP).

This passage gives a glimpse of the role, facilitating or of limitation, played by the medical institutions in the sports practice of mobility impaired people. In France, unlike England, the 
sporting movement for physically disabled people 'does not owe its existence to the medical world, nor to the one of reeducation' (Ferez et al., 2013, 41). It occasionally finds in it a recruiting pool which is essential to its development (reeducation centers) and is also submitted to its decisional power in international contexts (categorization of the athletes for example). Currently, the limitations to practicing sports imposed by the medical area are confronted with the growing desire of disabled people to practice extreme activities such as mountaineering. For Jean-François Porret, regaining natural places symbolizes the social, and medical, limits which must be overcome in order to re-constitute an identity proper. This recovering however must include assistance, from friends or a medical one, providing access to broken grounds.

During this expedition to Tibet, in May, 1993, in the Kula Kangri mountain range (7554 meters high), Porret manages to ascend to an altitude of 5600 meters. Accompanied by two mountaineering friends, a doctor, a nurse and a geologist ${ }^{11}$, he is towed up there by a 'small Tibetan horse'. He bivouacked during ten days in a camp located at an altitude of 4400 meters, using adapted and homemade camping gear (a double tent to fight against the wind, inflated mattress to avoid bed sores, quilted ski suit against the cold), which had been tested during the previous expeditions. Lastly, he achieved 'a magnificent descent all alone, in his ORWC, (...) much faster than the others who were on foot (...)'. This first 'real expedition' was a success and will be the starting point of many more. Since then, Porret launches out almost every year in a new expedition to various destinations (Ecuador, China, Jordan, Cape Verde, Senegal...).

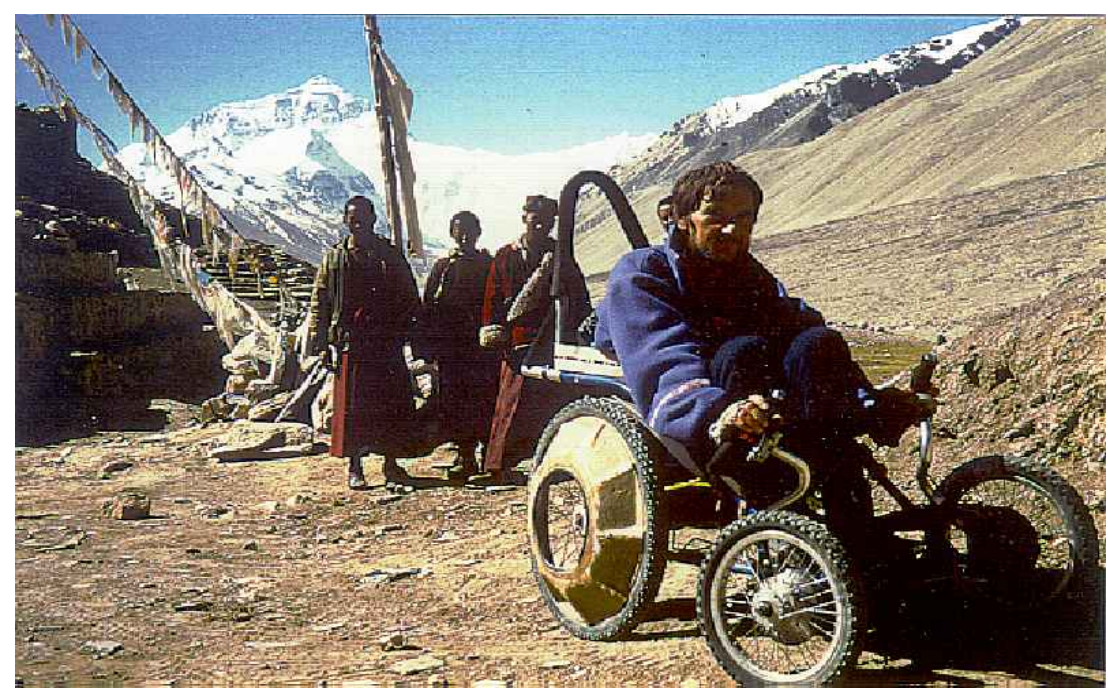

(Porret in Tibet in 1993, source: ftt.free.fr) 
Although the organization of these expeditions is 'done for him", he is at the origin of their conception and is in charge of them. He is the 'expedition leader' who has to organize the $\operatorname{logistics}^{12}$ and who is in charge of the relations with the local authorities ${ }^{13}$. For Porret, all the expeditions must have a 'handi [disabled] dimension' and a 'mountaineering with friends dimension' . Porret refuses any publicizing in the media, although it would help to acquire the necessary funds for the costly expeditions. The media seem excluded from the main idea: the idea of living a convivial adventure allowing to 'retrieve past sensations'. ORWC, presented as a convivial activity, also enables the person to reconstruct him/herself after an accident which induced an important mobility impairment.

Through his activities, Jean-François Porret explains that he aimed to promote an alternative to the 'competitive' aspect of ORWC which had developed in the United States. The world reference for all-terrain wheelchair riding is tied to the performances of the American John Davis who is, for the French ORWC pioneer, the first 'para' to have 'dared to launch his Cobra down able-people's mountain bike trails' $\left(H M, \mathrm{n}^{\circ} 99,1999: 40\right)^{14}$. The media coverage of these exploits seemed to promote a competitive and spectacular practice of ORWC in North America, thus attracting the economic world which, in return, encouraged its development both on an institutional ${ }^{15}$ and on a technological ${ }^{16}$ level. To this orientation, Porret opposes a 'more recreational activity (...) concerned with hiking and the search for autonomy out in nature' (id.: 41), which confirms his desire to generalize this activity. However, the cost of the equipment and the needs in terms of logistics limit the accessibility to it.

During the same year as the expedition to Tibet, the development of this activity took a new turn when Porret met Gilles Bouchet, a 37 year-old mountaineer, who became paraplegic three years after he did. By means of a professional network related to both the sports and the political worlds, the latter brought an 'economic' and 'technological' dimension to the development of ORWC riding.

\section{The encounter with Gilles Bouchet: From ORWC equipment innovations to adapted} overseeing.

At the time of his helicopter accident at the top of the Mont Blanc on September 6, 1991, Gilles Bouchet had been the Assistant Director of the National school of Ski and Alpinism (ENSA) ${ }^{17}$ of Chamonix for 4 years, as well as a mountain guide. He was a mountain 
bike and a hiking enthusiast. When he became paraplegic, the accident was perceived as 'an atomic blast' after which everything had to be 'reconstructed'. Carrying on with his former activities seemed impossible to him: 'at one point, I told myself, the outdoors is over'. During his sojourn at the reeducation center, at Saint-Hilaire du Touvet, near Grenoble, he was overseen by two 'gym teachers (...) who had an outdoor perspective', Pierre Martin and Jacques Lagarde, who made him aware of outdoor activities which are adapted to disabled people. They assured him that he would 'get back onto skies' (which he did in January, 1992) because the center, established in a mountain range, had developed 'sitting ski'18.

During his reeducation, Gilles Bouchet met Jean-François Porret and his Cobra, which made him realize 'that all is not lost', 'that things can still be done' and most of all, that he will 'be able to be out in the mountain, but in a different manner'. Bouchet then fixed his aim on being able to start practicing his passions again: '(...) in my head, I told myself that if I could do even just ten percent, then life would still have meaning'. Along with a friend, Bernard Laviolette, a regional technical counselor for sailing in the Rhône region (France), but also a specialist in optimizing sporting equipment, they worked to conceive and create equipment which would be adapted to mobility impairments for the mountain. They created and made, to begin, a cross-country skiing sled 'with bits of soldering pipe'. The equipment was then tested, with 'occasional failures', on the summits of Tignes. In the continuity of their work on the sled, Bouchet and Laviolette take an interest in ORWC, and even more so because the production of Castellano's Cobra stopped in 1995. The question of producing equipment which is adapted to mountain activities, whether for sitting ski or for ORWC riding, was an important issue to which Bouchet tried to find answers. With Bernard Laviolette, who involved the National Institute of Applied Sciences of Lyon (INSA), and more specifically the engineering students who had a top-level athlete status, Gilles Bouchet also contacted the 'mechanical engineering' section of the Annecy IUT (University Institution for Technology) to elaborate an ORWC. In this way, tinkering 'in the basement, at the back of the garage' is left behind in order to develop more sophisticated equipment in an 'apprentice's workshop of the Lycée Boisard [technical college] in Vaulx-en-Velin'19. They create the 'Dahu', inspired by Castellano's 'Cobra'. 'We named it the Dahu because it symbolizes [in French] «the lopsided » (...) both with respect to the slope and to the Handi [disabled person]. And also it is a mythical animal, which has paws of different lengths, and which is never seen'. The Dahu was more resistant and bigger than the Cobra ${ }^{20}$. Other than the question of making it, the cost of the equipment was also an obstacle which needed to be taken into account. The Dahu was cheaper and so 
more accessible than the Cobra. The idea was to make an ORWC which was 'easier to make using standard bicycle equipment (...) parts which are easier to change, stronger welding points (...)' (GB).

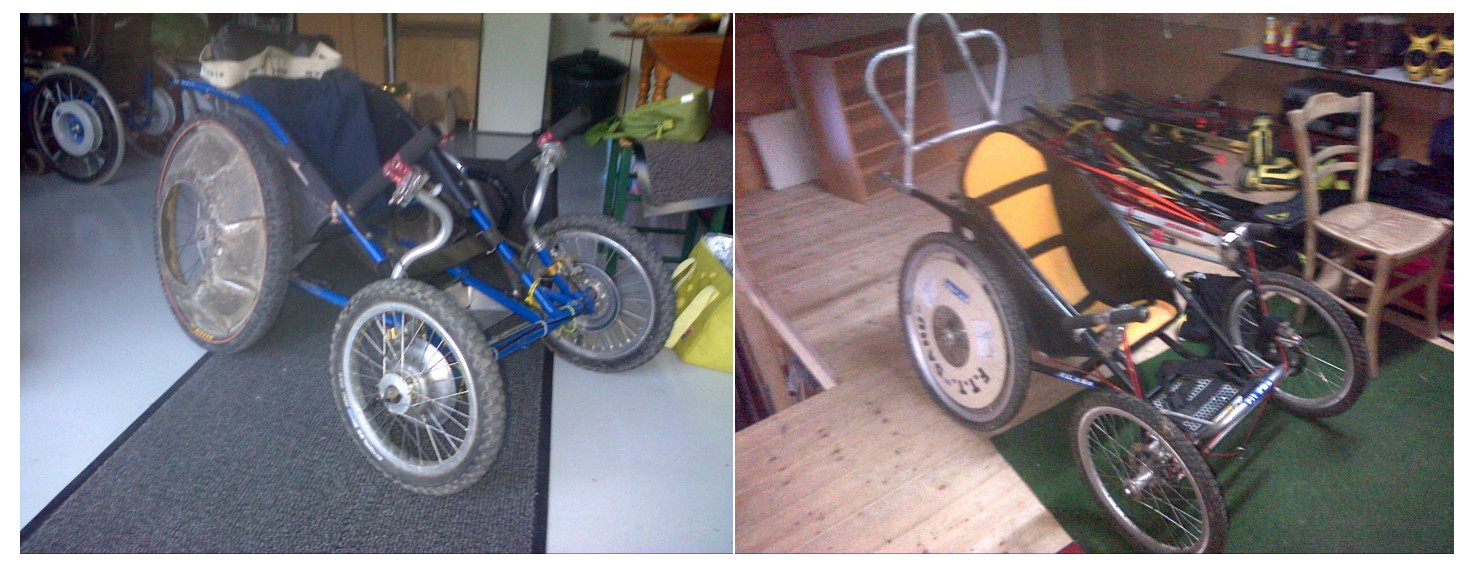

(Photos taken by Eric Perera in December 2014)
1) Jean-François Porret's Cobra
2) Gilles Bouchet's Dahu

They achieved their goal by creating 10 prototypes of the Dahu. The necessary funds for the project were obtained through sponsors such as the Rhone-Alpes Regional Council and the Handisport Federation, via the regional committees of the Isere, the Savoie and the HauteSavoie (French regions), who purchased a number of them in order to offer them to their affiliated associations. In 1994, Gilles Bouchet was one of the 6 laureates of the Georges Poirier Foundation which, 'under the aegis of the Fondation de France, helps individual physically disabled people to carry out their projects' (HM, nº82, 1994 ins. cov.). He won this prize as the 'creator of an all-terrain wheelchair or FTT [French acronym for ORWC] in France' (id).

Beyond the technological developments, and as an inspector for the Ministry of Youth and Sports, Bouchet also calls upon his professional and sporting network to promote outdoor and nature activities: '(...) it might get things moving. Because as it so happens, I am the guy who is involved, who is in the mountain, who had a good network, who knew the pros, who was close to the ministry'. He appealed to the political protagonists (notably the general and regional councilors) to finance the equipment adapted to nature activities ${ }^{21}$. The parasports regional committees and the local associations took part in spreading these activities and thus enabled to 'make evolve the image of physical disability and nature'. Gilles Bouchet understood that nature activities were going to take up more room in the parasports world at the cost of more 'classical' activities, such as wheelchair basket-ball for instance. The Winter Paralympics of 1992, which took place in Tignes, spark the interest of the local authorities 
concerning the access of physically disabled people to nature activities, notably the RhôneAlpes Region. The regional technical counselors (CTD) for Handisport de Savoie (with Bernard Thiévenaz) and of Isère (with Patrick Heydt) take part in and encourage the organizing of training courses dedicated to leisure activities (such as Alpine ski or crosscountry ski, for instance). However, Bouchet did not wish to promote a uniquely federal practice: 'it may be my refusal of stigmatization, so my idea was more to find the equipment and the adaptations so that I could go there with my family, rather than (with) an association which would be closed around disabilities. I wanted to escape welfare and dependency. There must be adapted hotels, decent adapted equipment and competent professionals. The aim was thus to fit into an economic way of reasoning'.

For this to happen, Bouchet contributed to the training of the competent overseers, such as ski and mountain bike instructors or mountain guides. With the Presidents of the mountain professionals' trade unions, they propose free continuing education courses enabling to oversee disabled people. The aim was to consider the disabled person as a 'client with specific needs'. In parallel, the Rhône-Alpes Region invested in some costly equipment (ORWC, cross-country sled and sitting skis), closely followed by the General Council of the Hautes-Alpes, thus equipping most of the French skiing schools ${ }^{22}$. These investments offered the opportunity of discovering nature activities with adapted equipment and qualified personnel, without any overcharge relating to the cost of the equipment and without solely depending on specialized structures such as the APF (French Association for the Paralyzed) or the Parasports associations.

At the end of the 1990s, eight types of ORWC were listed by Porret. Six of them originated in North America, while the two others were made in France: the 'Dahu' by Gilles Bouchet and Bernard Laviolette, and the 'Lozère' ${ }^{\prime 23}$, created the Ecole de Mines in SaintEtienne. The beginnings of an industrialization took shape with the aim of occupying an innovating market, thanks to a practice which is part of nature activities, a field that is attracting more and more disabled people. In parallel, a policy of accessibility to leisure and touristic grounds favoring disabled people was carried out on a national level from the year 2000 onwards. The process initiated by Porret was therefore part of a more global approach to accessibility, as it would be later conceived within the frameworks of the quality labeling policies "Tourism and Disability" after the year 2000, and then "Destination for all" after 2011 (Amiaud 2012). 


\section{Institutionalization and sportivization of ORWC riding in France (2000): 'truly a sport of sharing and diversity'}

As we have seen, the practice of ORWC developed outside the federal system, through 'mountaineers' who wished to pursue their passions. Thus, they developed all-terrain wheelchair riding with the aim of going hiking in the mountains with family and friends, or going on expeditions in small groups, 'backpacker style' (JFP). In addition to these initiatives, we also observed a federal project aiming to develop adapted nature activities. At first developed locally by regional committees (Rhône-Alpes, Isère, Pyrénées), this project spread on a national scale with the creation of training courses for the professionals who work in the field of tourism and leisure activities, since they found themselves more and more solicited by people with disabilities (Reichhart, 2011).

When Gérard Dejonghe took up his functions within the FFH as the manager for the development of the APPN (nature activities), in 1983, the aim of the federation was to promote nature activities from a leisure point of view, in addition to the competitive side of the activity which prevailed until then. In support of the growing local initiatives ${ }^{24}$ which proposed one-time events, training courses or regular practice, the federation initiated a training process for the overseeing and the quality-labeling of these activities, in order to encourage their accessibility to disabled people. The creation of parasports qualification certificates (CQH in French), in 1996, offering the possibility of additional training for professionals of the sporting world (National Qualification), followed by the creation of a 'Parasports Leisure Area' (ELH in French) quality-label, in 1998, contributed to setting up the conditions of an adapted reception for disabled people within nature activities structures. As well as taking an inventory of these structures and developing them, the goal of these dispositions was also to create a framework for these new activities which elicit a growing enthusiasm and which necessitate securing and an adapted overseeing. In 2001, the 'Tourism \& Handicap' quality-label was created by the ministry of Tourism, and more specifically by the Tourism and Handicap Association (ATH), in the context of a policy promoting the access to holidays for all and the integration of disabled people, encouraging the development of accessibility to natural sites for disabled people. For Mai-Anh Ngo and Anne Marcellini (2014), this process of quality-labeling is to be linked to the 'modifications produced by public policies, which were not directly centered around sports' (pp.144), notably to the law 
$\mathrm{n}^{\circ}$ 2005-102 of February 11, 2005, for the equality of rights and opportunities, the participation and the citizenship of disabled people, which constituted a real turning point. For physical nature activities, the authors also evidence the way in which 'the appearance of sustainable development in public policy encourages the interest which is induced within the FFH' (id:: 147).

In this context, ORWC riding benefited from a certain level of attention from the federal level. The growing number of articles relating to ORWC riding in the Handisport Magazine from the year 2000 onwards, but also those published in certain specialized journals (the Trek journal of March, 2000), act as evidence for this enthusiasm. Consequently, how did the practice evolve during this period? Did we assist to a 'sportivization' (Guay, 1993), in other words to a development of its competitive side, as it seemed to be the case in the United States, and which would affect the idea of discretion and conviviality initiated by the French pioneers? Through the analysis of the journals produced by the FFH, we made an inventory of all the events in which ORWC was proposed. We were able, at first, to identify different forms of events: multi-sports long distance hikes, introduction courses, hikes which were organized by associations and, finally, training courses aimed at professionals in the field of leisure and mountain sports. Next, we noted that the all-terrain wheelchair was considered as an innovating device, promoting openness and conviviality. These assets truly illustrate the regional committees' desire to 'promote sports and leisure activities' which constitute 'one of their major lines of development' (HM, n $97,1998: 55)$. From there on, we can see the beginnings of an institutionalization process of off-road wheelchair riding. In 2001, the term 'éftétiste' (phonetic writing of the French acronym for ORWC, designating a person who practices that activity, similar to an 'owearedoubleyoucee-er'), appeared for the first time and its practice was clearly defined. The 'éftétiste', using his 'device equipped with mountain bike wheels and powerful disk brakes' gains access to 'mountain trails which are normally inaccessible', with assistance (human or mechanical), in order to 'partake in the great joy of an entirely autonomous descent' $\left(H M, \mathrm{n}^{\circ} 105,2001: 20\right)$. A guide for the 'proper practice' and an 'expert letter' are edited in order to alert to the dangers and the precautions which should be taken (id.: 21-22). Practicing alone is forbidden and the presence of two guides/overseers, or qualified and recognized personnel (via the parasports qualification certificate), within 'registered structures', is strongly recommended to guarantee a secure practice. Although these precautions naturally promote a mixing of practices (able-bodied people on mountain bikes or on foot who accompany those in an ORWC), it is however emphasized that there should be an 
'educational move for bringing autonomy to the athlete. For the disabled hiker to be the actor of his activity!' (HM, $\left.{ }^{\circ} 128,2007: 26\right)$. The practitioner's autonomy must be at the center of preoccupations, as it was promoted by the FFH. In this context, what forms of ORWC riding can be observed in France? Do we assist to a specifically French form taken on by the development of this practice?

On the contrary of what seemed to be happening in the United States, the FFH did not want to see a competitive and spectacular practice ${ }^{25}$ develop, 'essentially for insurance and security reasons' $\left(H M, \mathrm{n}^{\circ} 105,2001: 22\right)$. With a will to encourage a more leisurely practice, the institutional protagonists explained to those who would like to take up the sport, that 'ORWC is absolutely not an extreme sport' (HM, $\left.\mathrm{n}^{\circ} 128,2007: 27\right)$. However, it sometimes happened that certain regional parasports committees organized competitions, some as timed slaloms or 'multi-sports long-distance treks', during which mixed teams compete with each other in various nature activities (ORWC riding, Kayak, Archery, Sailing). The 'raids' [French term for long-distance treks] and 'challenges' are the types of competition which received the most media coverage from the Handisport Magazine, possibly because they came closer to the image of diversity and autonomy-gaining of the parasports athletes which was promoted by the FFH. In the descriptions the journal makes of these mixed raids, terms are used such as 'sporting spirit', 'physical effort', 'mutual aid', 'solidarity' and also 'conviviality' $\left(H M, \mathrm{n}^{\circ} 130\right.$, 2007: 36-37), a set of values which act as evidence of the sportivization process. However, the FFH prefered to support the local authorities in their development of hiking, which was closer to the local preoccupations. On December 2, 2007, a national commission for hiking was set up. It regrouped all the people who were part of associations or institutions which developed this activity $\left(H M, \mathrm{n}^{\circ} 128,2007: 16\right)$ in order to organize the practice of it throughout the national territory, by training the overseeing personnel $(\mathrm{CQH})$ and by setting up relations of collaboration with local protagonists (associations, committee representatives, people from the field of tourism, etc.). In 2008, through this commission, the FFH entered into a partnership with the French federation for hiking (FFRP), when the latter announced the year of 'hiking for all', in order to take part in the reflection surrounding the adaptation of the hiking trails for disabled people and the training of the overseers $\left(H M, \mathrm{n}^{\circ} 132,2008: 42-43\right)$. The goal of the project was notably to promote the practice of ORWC for all, since it seemed limited to a handful of privileged people, mainly because of its high cost. The aid from the side of the associations therefore seemed to be the main means of dissemination of this practice to the largest possible number. 
In actual fact, during that period, the FTT's activity developed in two directions, which at the same time were distinct but complemented one another. On the one side, there were the 'pioneers' who advocated an 'autonomous' practice of ORWC, and to whom the expeditions seemed to be the principal end. On the other side, there were the sporting associations in relation with the federal movement, but also with the field of politics, who promoted a regular practice surrounded by qualified overseers. All in all, whichever direction was taken, the practice of ORWC was generally understood as 'truly a sport of sharing and diversity' (HM, $\left.\mathrm{n}^{\circ} 128,2007: 27\right)$. These principles were also those mentioned by the pioneers in the context of the expeditions: 'The fact that there are disabled and able-bodied people, there was a great ambiance, mutual aid, that was magical. The is always a great atmosphere' (JFP). The expedition projects made by Porret, and then by Bouchet, related to other forms of exploits than those achieved by Davis and by his successors nowadays ${ }^{26}$ : 'The expeditions are human adventures, and ORWC is the means to carry them out. The aim is not an ORWC "raid", the aim is to live something and the ORWC allows to reduce the differences and thus to live it out'. However, their practice had to be distinguished from the 'APF outlook, the perspective of competitive, structured, parasports' since they considered theirs as a 'much more free practice, family-friendly, with friends' which allows to 'commune with nature ${ }^{27}$. In this context, practices which could be interpreted as 'resilience ${ }^{28}$ strategies took place within a framework which truly symbolized sporting 'counterculture'. The 'Californian' (Pociello 1981) or 'fun' (Loret 1990) sports are, by nature, in opposition with the competitive model, with any normalization, and promote empathy with the environment. Thus the pioneers of ORWC demonstrated a will to develop a practice which would push back the environmental barriers. Can the principles of freedom and autonomy which they pursued, and which are often used by the federal protagonists $\left(H l m, n^{\circ} 142,2011,44\right)$ be found within the safety policy which was carried out by the FFH? The 'never alone' rule (id.) seemed to go against the idea of selforganizing the expeditions. A frame of mind which is supposed to 'change the image of disability' (GB) and of the disabled person. The collective engagement to heave the people in ORWC up to the most abrupt summits, in order then for them to hurtle down them in all autonomy, offers the possibility of living an experience and then sharing it with others. Thus, the collective experience of disability, through the participation to expeditions, presents itself as 'an institutionalized arena for new experimentations of the body, of movement and of space, of elaboration and of transmission of knowledge and norms', and enables to 'figure as "a valid interactee", to educate the able-bodied, and even to seduce them (...)' (Ville et al., 2015: 125). 


\section{Conclusion: The institutionalization of ORWC riding, a practice for oneself and for all.}

Developed in France from the 1990s onwards, by enthusiasts who, after their accident, decided to tinker with sporting equipment 'at the bottom of the garage', ORWC riding seems nowadays to be institutionalized, notably because of the numerous options which it offers (hiking, descent, tourism). It emerged as a way to 'go back to a previous life', and was seen as a 'pair of mountain boots' (GB). Later, ORWC riding was progressively recognized as a practice which enabled sharing, disabled-abled diversity, access to natural spaces and autonomy, which are principles that are promoted by the FFH in its project for development and opening to the public. After the year 2000, ORWC became a federated activity, leading to the creation of the hiking commission and to the nomination of a sporting director in charge of its development in 2007. Next, we assisted to the progressive codification of its practice: safety rules, increasing technicality, and training of the overseers. Presented as a 'wild' practice by the pioneers, ORWC riding conformed to federal demands. Its development was also linked to the national policy favoring the social participation of disabled people which encouraged accessibility to natural spaces and the development of adapted nature activities.

The institutionalization process of ORWC riding does not however seem to have attained its limits. Presented as an activity which encourages autonomy, the technological progress with which all-terrain wheelchairs develop is aimed at increasing it. Recently, with the appearance of electric ORWC, there is a 'change of paradigm', according to Jean-François Boury, a regular hiker who assisted to the beginnings of off-road wheelchair riding and who takes part in an innovating project of electric ORWC. 'Through motorization and assistance, autonomy is complete'. It allows to widen the field of possibilities for riding with less human aid, to such an extent that ORWC pioneers such as Porret and Bouchet acquired some. Now, there is a radical evolution with the electric ORWC. We are changing terrains. I bought one, because there is no more threat of being stuck by a 200-meter slope. With the (electric) ORWC, we can discover new places, and with the evolution of batteries, I go on 30-40 km outings with a 900meter climb without needing any assistance or any help. Whereas before, this would have entailed pretty heavy logistics.' (GB). Thus, there is no need to be towed by people or by animals anymore, the autonomy is true both for the ascent and the descent. Electric ORWC allow to be free of dependence towards the able-bodied guides, and even to compete with mountain-bikers: 'the mountain bikes are having trouble following us' (GM). In this way, the total autonomy which is offered by the electric ORWC seems able to transform this practice and provides new ways of riding, which could maybe attract new people, but most of all 
transform the initial outlook of the activity, centered around sharing and diversity. Up until then, this approach had emphasized the relation of inter-dependency (exchanges, ties, solidarity) which takes place between the 'éftétiste' and the different aids enabling his/her practice (the means of towing for instance). The institutional protagonists also put forward this specificity as an essential element for the development of ORWC, that is to say as a practice favoring integration within society and adapting the layout of the grounds through access to touristic activities (such as hiking).

The technological evolution of the wheelchair towards electricity leads to a development in the mobility possibilities for the users and to a transformation of their relation to the world. This opportunity of greater autonomy, which sometimes seems very relative, often perceived as a synonym for liberty, of independence, referring to a situation in which the subject, the group or the society could set its own rules, could govern itself with its own laws (auto nomos), will it not deeply change the initial outlook? Will we not, after all, develop into a similar practice as the North-American one, with the goal of individual achievement rather than sharing and coming closer to nature? Is the technological innovation, which is necessary to its development, not corrupting the social links which regulate the activity? We find ourselves limited in the analysis to answer these questions without more firsthand empirical data. The observation of ORWC expeditions would enable us to integrate the in situ discourses and behaviors which might shed light on the (inter)relations and the subjectivity of the protagonists.

\section{Notes}

${ }^{1}$ The FFH was born from the union of the French Federation of Sports for the Physically Disabled (FFSHP) and the Omnisport French Federation for the Physically Disabled (FFOHP) (Ruffié and Ferez 2013).

${ }^{2}$ Philippe Berthe was the president of the Sports Club for the Wounded of France (ASMF) which was created in May 1954, before becoming president of the Sports Federation for the Physically Disabled of France (FSHPF) on August 10, 1963 (date of his official recognition); Pierre Volait was his successor in November 1966, 'heading the FSHPF with the aim of strengthening the management methods and its financial structure' (Ruffié and Perera 2013, 63).

${ }^{3}$ The 'standing' practice, sometimes possible in cases of amputation of the lower limbs, is opposed to 'sitting' ski, which is a sport invented for paraplegic and/or quadriplegic people.

${ }^{4}$ The discourses which were produced during our interviews will be indicated with quotation marks and be italicized.

5 The Handisport Magazine journal appears in 1982. It follows a series of five journals published by different associations which federated the parasports movement in France during the 1950s and up to the year 2000: the Revue des mutilés de France [journal for disabled war veterans] (1955-1959), the ASMF Magazine (1959-1963), the Second Souffle [second breath] 
(1964-1981), the FFHOP Magazine (1972-1977) and the Handisport Magazine (from 1982 onwards). Since 2011, the journal's new name is Handisport Le Mag.

${ }^{6}$ Before ORWC appeared, there was the 'Joëlette' or the 'Joëlle'. It was conceived by a mountain guide, Joël Claudel, who wanted to take his nephew, suffering of myopathy, on outings. He founded the Handi Cap Evasion Association in the Hautes-Alpes in 1988. It is a 'mono-wheel all-terrain wheelchair, capable of going anywhere, but which necessitates the presence of two assisting carriers'. (HM, $\left.\mathrm{n}^{\circ} 99,1999: 42\right)$.

The Cobra $(20 \mathrm{~kg}-125 \mathrm{~cm} \times 75 \mathrm{~cm} \times 90 \mathrm{~cm})$ is an ORWC which is 'easy to handle, lightweight and sturdy enough to do anything (...) it offers an efficient adaptation (for the) quadri(plegics)' (HM, $\left.\mathrm{n}^{\circ} 99,1999: 42\right)$.

${ }^{8}$ Porret associates his practice with mountain-biking (in French, VTT where V stands for the Bike), thus creating the term FTT (the F standing for the Chair).

${ }^{9}$ The Ftt.free.fr website was created in July 2000. Currently, over 200 adapted courses, both in France and throughout the world, are listed there.

${ }^{10}$ Very long hike in hilly regions which relate to the concepts of length and of autonomy. The sleeping conditions can be variable: tents, refuge, staying with the locals, cottages, hotels. This activity, continually developing, is considered today as a way of travelling in itself.

${ }^{11}$ Porret explains that he also wanted to give a scientific character to the expedition in order to lend strength to his application with the Chinese authorities.

${ }^{12}$ The month-long expeditions, including 6 people, involved renting two all-terrain vehicles and one truck to carry all the equipment and food.

13 '(...) I took on this part because I was just about the only one who spoke English. But it was tiring because we had to have meetings, take stock of the situation every night, there was a political commissioner. In the evenings is when we have medical care, so it isn't easy. However, it was full of extraordinary experiences'.

${ }^{14}$ Extract from the first article about ORWC which was published in Handisport Magazine. It was called "All-terrain Wheelchair riding. A sport in full expansion" and was written by JeanFrançois Porret himself.

${ }^{15}$ According to Porret, three ORWC competitions were organized in 1999 by the NORBA (National Off-Road Bicycle Association, USA): downhill, dual slalom, and cross-country (HM, n99, 1999: 41).

${ }^{16}$ During the 1990s, various other types of three or four-wheeled ORWC were created in the United States: the Buzzard, the Enduro, the Phoenix, the DHW-1, the One-off $\left(H M, \mathrm{n}^{\circ} 99\right.$, 1999: 42).

${ }^{17}$ Training school for mountain guides and ski instructors.

${ }^{18}$ The first prototypes of 'sitting' skis were created at the centre in Saint-Hilaire du Touvet (Le Roux, Haye and Perera 2014).

${ }^{19}$ It is a technical college which enables him to create and make durable adapted equipment without having to enter into commercial logistics (patents, etc.).

${ }^{20}$ The Dahu weighs 25 kilograms $(140 \mathrm{~cm} \times 85 \mathrm{~cm} \times 70 \mathrm{~cm})$ against 20 kilograms for the Cobra $(125 \mathrm{~cm} \times 75 \mathrm{~cm} \times 90 \mathrm{~cm})$.

${ }^{21}$ According to Gilles Bouchet, the Rhône-Alpes region was one of the first to develop sitting ski and ORWC riding.

${ }^{22}$ These types of actions were also carried out in the Pyrénées and the Alpes Maritimes regions.

${ }^{23}$ The 'Lozère', conceived by BFP Electronique, is described as 'a chair for excursions, half way between a city wheelchair and a truly all-terrain contraption' (HM, $\left.\mathrm{n}^{\circ} 99,1999: 42\right)$.

${ }^{24}$ Gilles Bouchet created the association 'Sports Leisure Tourism Development Handichallenge' in 1993 in Annecy in order to promote tourism for disabled people, via 'the 
development of products, equipment or adapted activities'. The association proposes to 'organize days for trying out the Dahu and training courses' (HM, $\left.{ }^{\circ} 99,1999: 43\right)$. Other associations propose ORWC riding in the context of 'multisport raids' or of 'discovery days' for nature activities.

${ }^{25}$ According to Porret, the American championships of ORWC riding attract new participants from Japan (see the website ftt.free.fr in the news section)

${ }^{26}$ Stacy Kohut, a Canadian mountain biker who became paraplegic, 'is one of the most emblematic riders of the free style ORWC scene' according to The Rider Post, a website specialized in extreme sports. http://www.theriderpost.com/dirt/stacy-kohut-detruit-lebikepark-de-whistler-en-ftt/, consulted on January 4, 2016.

27 'What I wanted to say was that: we don't touch nature, however we do foresee the adaptations which will enable the disabled to gain access to this untouched nature. To me, that's what the Dahu is, and we don't touch nature' (JFP).

28 A term used originally in the field of physics of materials, which was borrowed in psychology to name the capacity of an individual to come out as 'the winner' of an event which could have been traumatic, with renewed strength. Analyzing this process in the context of sports, Anne Marcellini (2005) demonstrates how it is a way of redefining oneself and of overcoming disability.

\section{References}

Anaut, Marie. 'Résilience et personnes en situation de handicap', Reliance, 15, 1 (2005): 1618.

Amiaud, David. 'La politique publique "tourisme et handicap" : du lieu au territoire ", Mondes du Tourisme, 5 (2012): 31-46.

Barral, Catherine, Paterson, Florence, Sticker, Henri Jacques, and Chauvière, Michel. (dir.). 2000. L'institution du handicap. Le rôle des associations. XIXe-XXe siècles. Rennes: PUR.

Ferez, Sylvain, Thomas, Julie and Ruffié, Sébastien, L'Amicale sportive des mutilés de France (1954-1963), in Corps, Sport, Handicaps. Tome 1. L'institutionnalisation du mouvement handisport (1954-2008). Edited by Ruffié, Sébastien, and Ferez, Sylvain (dir.), 31-48. Paris: Téraèdre.

Ferrarotti, Franco. 1983. Histoire et histoires de vie. La méthode biographique dans les sciences sociales. Paris: Librairie des Méridiens.

Fougeyrollas, Patrick, Boucher, Norman, Fiset, David, Grenier Yan, Noreau, Luc, Philibert, Mathieu, Gascon, Hubert, Morales, Ernesto and Charrier, Francis. 'Handicap, environnement, participation sociale et droits humains : du concept d'accès et sa mesure'. Revue développement humain, handicap et changement social, hors-série (2014): 0-0.

Guay, Donald. 1993. La culture sportive. Paris : PUR.

Marcellini, Anne and Villoing, Gaël (dir.). 2014. Corps, sport, handicaps. Tome 2. Le mouvement handisport au XXIème siècle. Lectures sociologiques. Paris: Téraèdre.

Ngo, Mai Anh and Marcellini Anne. 2014. "Influences externes sur l'évolution de la FFH", in Corps, sport, handicaps. Tome 2. Le mouvement handisport au XXIème siècle. Lectures sociologiques. Edited by Marcellini, Anne and Villoing, Gaël (dir.), 141-151. Paris: Téraèdre.

Revel, Jacques (dir.). 1996. Jeux d'échelles. La micro-analyse à l'expérience. Paris, Gallimard and Le Seuil, coll. Hautes Études. 
Le Roux, Nathalie, Haye, Lisa, and Perera, Eric. 2014. «Les innovations pour le ski handisport et l'accès à la pratique ", in Corps, sport, handicaps. Tome 2. Le mouvement handisport au XXIème siècle. Lectures sociologiques. Edited by Marcellini, Anne and Villoing, Gaël (dir.), 141-151. Paris : Téraèdre.

Loret, Alain. 1995. Génération glisse : dans l'eau, l'air, la neige: la révolution du sports des 'années fun '. Paris: Autrement.

Pociello, Christian.1981. Sports et société. Approche socioculturelle des pratiques. Paris: Vigot.

Reichhart, Frédéric. 2011. Tourisme et handicap. Le tourisme adapté ou les loisirs touristiques des personnes déficientes. Paris: L'Harmattan.

Ruffié, Sébastien and Ferez, Sylvain. (dir.) 2013. Corps, sport, handicaps. Tome 1. L 'institutionnalisation du mouvement handisport (1954-2008). Paris: Téraèdre

Ruffié, Sébastien and Perera, Eric. 2013. ' De l'ASMF à la FSHPF (1963-1967). Des amicales au regroupement fédéral', in Corps, sport, handicaps. L'institutionnalisation du mouvement handisport (1954-2008). Edited by Ruffié, Sébastien and Ferez, Sylvain. Paris: Téraèdre

Ville, Isabelle, Fillion, Emmanuelle, and Ravaud, Jean François. 2014. Introduction à la sociologie $d u$ handicap. Histoire, politiques et expérience. Louvain-la-Neuve: De Boeck. 